\title{
Isu Terorisme dalam Jurusan Hubungan Internasional Perspektif Islam
}

\section{Siti Muslikhati}

Jurusan IImu Hubungan Internasional, Fakultas IImu Sosial dan IImu Politik, Universitas Muhammadiyah Yogyakarta

Ringroad Barat Tamantirto, Kasihan, Bantul 55183

Email:sitimuslihati@umy.ac.id

\begin{abstract}
The fight against terrorism must depart from the settlement of the core of problems. One of the most important roots of terrorism today is the injustice and imbalance in the system of international relations which in turn fosters an attitude of double standards to the holders of international domination and hegemony, the US and its Western allies. Only with the creation of a new international order which is fair, then terrorism can be reduced, thus creating world peace.

Keywords:terrorism, Al Fatah, civil war, United States, Islamic World
\end{abstract}

\begin{abstract}
Abstrak
Usaha memerangi terorisme harus berangkat dari penyelesaian terhadap akar masalah (core of problems). Salah satu akar terpenting terorisme saat ini adalah ketidakadilan dan kepincangan dalam tata hubungan internasional yang pada gilirannya menumbuhkan sikap standar ganda (double standard) pada pihak pemegang dominasi dan hegemoni internasional, yakni AS dan sekutu-sekutu Baratnya. Hanya dengan terciptanya tata internasional baru yang adil, maka terorisme bisa dikurangi, dengan demikian tercipta perdamaian dunia.

Kata kunci:terorisme, Al Fatah, perang peradaban, Amerika Serikat, Dunia Islam
\end{abstract}

\section{PENDAHULUAN}

Runtuhnya Uni Soviet pada awal tahun 1990-an telah menyebabkan Perang Dingin kehilangan makna. Warga dunia kemudian berasumsi bahwa perang dan kekerasan telah berakhir dan kita tinggal menunggu terciptanya kondisi aman, damai dan sejahtera. Namun, kita menyaksikan betapa harapan itu makin jauh dari kenyataan. Maraknya teror bom dan aksi kekerasan menjadi fenomena baru yang muncul di era pasca Perang Dingin. Sasaran pemboman tidak lagi dipilih-pilih:mulai dari gedung pemerintahan, swasta, tempat-tempat umum, hingga rumah ibadah. Korban jiwa berjatuhan tanpa memandang lagi anak-anak, orang dewasa, laki-laki maupun perempuan; belum lagi yang luka-luka. Masyarakat pun merasa khawatir dan takut terhadap kondisi keamanan maupun keselamatan dirinya.

Masyarakat beradab pada zaman modern sekarang ini tidak ada yang membenarkan aksi apapun yang tergolong terorisme. Meskipun terdapat kesulitan untuk mendefinisikannya, namun secara populer terdapat pandangan umum bahwa terorisme adalah setiap tindakan kekerasan politik yang tidak memiliki justifikasi moral dan hokum (Azra, 2002:80). Secara singkat bisa dikatakan bahwa terorisme merupakan sebuah bentuk kekerasan langsung atau tidak langsung, yang dikenakan pada sasaran yang tidak sewajarnya mendapat perlakuan kekerasan itu, dan dengan aksi tersebut dimaksudkan agar terjadi rasa takut yang luas di tengah-tengah masyarakat.

Tulisan ini akan mencoba untuk menganalisis apa dan siapa sebenarnya yang ada di balik isu terorisme 
dan ekstremisme, kepada siapa pula tudingan itu diarahkan, serta bagaimana pandangan Islam tentang terorisme. Dengan analisis ini diharapkan terlahir sikap yang rasional dan proporsional menghadapi isu yang berkembang di sekitar kita.

\section{PEMBAHASAN}

ISU TERORISME DAN DASAR-DASAR PANDANGAN DUNIA AS

Mengapa isu terorisme muncul ? Dalam menjawab pertanyaan ini kita akan mencoba untuk menganalisisnya dengan sebuah kaidah "perceptions are guides to actions"(Papp, 1988:154). Dalam kerangka ini diasumsikaan bahwa tindakan seseorang atau sebuah negara sangat dipengaruhi oleh nilai-nilai, keyakinankeyakinan dan kognisi-kognisinya. Sebuah isu muncul tidak terlepas dari aktor yang membawa isu tersebut. Dalam isu terorisme ini, kita semua bisa menyadari bahwa Amerika Serikat (AS) adalah pihak yang paling nyaring berkampanye tentang anti-terorisme.

Sesungguhnya tindakan atau strategi AS sangat dipengaruhi oleh bagaimana dia memandang dunia internasional. Pandangan dunia AS bertolak dari masalah sekitar kebebasan politik. Kebebasan, yang diartikan sebagai penentuan nasib diri sendiri, mayoritas adalah penguasa, dan hak membantah, adalah tujuan tertinggi dalam hierarki nilai-nilai inti(Jones, 1992:55). Ancaman utama bagi kebebasan adalah kecenderungan inheren pemerintah untuk berkembang tanpa batas dan mengikis hak-hak warga negara. Obsesi yang mewarnai keseluruhan sistem adalah kesiagaan abadi melawan despotisme (kesewenangan). Dalam konteks masyarakat internasional, kebebasan individu berarti prinsip kemerdekaan nasional, sedangkan pemerkosaan kedaulatan teritorial dan campur tangan asing pada masalah-masalah domestik setara dengan pelanggaran hak-hak individu. Citra mengenai agresor internasional merupakan unsur penting dalam sistem kepercayaan Amerika.

Dalam hampir sepanjang sejarahnya, orang-orang Amerika memiliki keyakinan bahwa AS merupakan negara yang berbeda dengan negara yang lain. AS merupakan bangsa modern pertama, yang memiliki tugas-tugas dan misi-misi spesial. AS sering membanggakan dirinya sebagai "champion of democracy" (juara demokrasi), dan "the guardian of democracy" (pengawal demokrasi) dengan tradisi demokrasi yang kokoh sejak diproklamirkannya Deklarasi Kemerdekaan 4 Juli 1776 hingga kini.

Sebelum Perang Dunia I (PD I), AS secara relatif tidak terlibat dalam panggung dunia. Isolasionisme merupakan landasan penting kebijakan luar negerinya pada periode ini, karena kepentingan keamanan Amerika hampir tidak tersentuh oleh pasang surut politik dunia. Ketika kerukunan dunia secara relatif terbalik di tahun 1914 dengan pecahnya Perang Dunia I, netralitas AS mulai goyah. Kesamaan bahasa dan tradisi maupun ikatan dagangnya dengan Inggris, merupakan faktor yang membuat netralitasnya tidak bisa dipertahankan. Perang dipandang sebagai masalah moral tentang demokrasi dan kesusilaan (Inggris) melawan kediktatoran dan barbarisme (Jerman). Keharusan terlibatnya Amerika dalam PD I dinyatakan oleh Presiden Woodrow Wilson sebagai tanggung jawab Amerika "to make the world safe for democracy in a war to end all wars"(Papp, 1988:173). Pada periode PD I sampai dengan PD II, citra agresor dialamatkan kepada tiga kekuatan fasis, yaitu Jepang yang militan, Adolf Hitler (Jerman) yang fanatik serta Benito Mussolini (Italia).

Penyelesaian tahun 1945 yang mengakhiri kekerasan PD II dalam waktu yang sama menciptakan basis Perang Dingin. Amerika Serikat dan Uni Soviet bercerai sebagai sekutu dalam perjuangan bersama melawan fasisme dan mulai terlibat dalam kompetisi berkepanjangan memperebutkan pengaruh politik atas Eropa, Asia dan dunia. Dalam pidatonya mengumumkan Doktrin Truman 1947, Presiden Harry S. Truman menyejajarkan agresi komunis (dalam rezim yang totaliter) dengan agresi Nazi yang mendahuluinya.

Citra agresor ini melemah dengan meredanya Perang Dingin. Munculnya aksi 'terorisme' yang dilakukan kelompok Al-Fatah terhadap atlet-atlet Israel di Olimpiade Munich (pertengahan tahun 70-an), membuat negara-negara besar, terutama AS, 
berkepentingan untuk melawan terorisme. Setelah itu banyak diselenggarakan konferensi dan seminar internasional serta ditetapkanlah berbagai hukum dan undang-undang untuk membatasi aksi-aksi yang dapat digolongkan sebagai terorisme. Dinas Intelijen Amerika dan Dinas Intelijen Inggris dalam sebuah seminar yang diadakan untuk membahas makna terorisme pada tahun 1979 telah menyepakati bahwa terorisme adalah penggunaan kekerasan untuk melawan kepentingan-kepentingan sipil guna mewujudkan target-target politis. AS membuat opini umum yang bersifat mendunia agar seluruh dunia melawan aksi-aksi terorisme dan ekstremisme.

Berakhirnya Perang Dingin telah mengantarkan Amerika menjadi leluasa untuk menggelindingkan opininya tentang terorisme. AS berhasil memaksakan perlunya dibuat rekomendasi anti terorisme pada KTT negara-negara G-7 yang diselenggarakan di Prancis (1996). Untuk itu, AS telah menetapkan dan mengeluarkan undang-undang perlawanan terhadap terorisme yang disetujui Senat AS pada tahun 1997. Berdasarkan rekomendasi dan undang-undang tersebut, AS dapat memata-matai siapa pun dan di mana pun orang atau pihak yang dituduh sebagai teroris. AS berhak menangkap, bahkan menculiknya. AS juga berhak menjatuhkan sanksi yang layak bagi mereka seperti penahanan, interogasi, deportasi, dan pencabutan kewarganegaraan; tanpa memberi hak kepada si tertuduh untuk membela diri atau hadir di depan pengadilan. AS juga berhasil memaksa organisasi-organisasi regional untuk membuat rekomendasi untuk memerangi terorisme, sebagaimana yang diratifikasi oleh Mesir, Sudan, Suriah, Yordania. AS pun berhasil memaksa negera-negara di Asia Tengah (seperti Uzbekistan, Kirgizstan, Tajikistan) untuk membuat kerjasama intelijen guna memerangi terorisme. Tampaknya AS juga yang menekan negaranegara ASEAN untuk meratifikasi hal yang sama pada KTT ASEAN.

Di dalam "Rencana Strategis AS dalam Hubungan Internasional" yang dikeluarkan Februari 1999 disebutkan bahwa tujuan kepemimpinan internasional AS adalah menciptakan kemakmuran yang lebih aman dan dunia yang demokratis demi keuntungan bangsa Amerika. Sementara, masih menurut dokumen tersebut, untuk mencapai hal itu AS memerlukan kehadirannya di belantika internasional secara kuat, kualifikasi dan motivasi yang tinggi, diversifikasi orang dalam mengurusi dalam dan luar negeri, menjalin komunikasi yang intensif dengan publik baik dalam maupun luar negeri, serta instrumen-instrumen politik, militer, dan ekonomi untuk meraih kebijakankebijakan luar negeri bangsa AS (Lihat United States Strategic Plan For International Affairs. Dirilis oleh Office of Resources, Plans, and Policy, U. S. Departement of State, Washington, DC, February 1999). Arah semua ini adalah mengembangkan ideologi kapitalisme yang dianutnya, disamping mencapai kepentingan nasionalnya. Dalam Rencana Strategi AS (2000) dinyatakan bahwa demokrasi dan HAM (sebagai ide pokok kapitalisme) merupakan komponen pusat dari kebijakan luar negeri AS. Disamping itu, diterakan dalam rencana strategis tersebut bahwa AS dalam mendorong demokrasi tidak hanya mempromosikan nilai-nilai dasar AS seperti kebebasan beragama dan hak-hak buruh, melainkan juga menciptakan sarana global yang lebih aman, stabil, makmur hingga AS dapat meningkatkan kepentingan-kepentingan nasionalnya (U.S. Departement of State Strategic Plan (2000). Dirilis oleh Office of Management Policy and Planning U.S. Departement of State, 25 Oktober 2000). Salah satu implementasi dari keadaan yang lebih aman dan stabil tadi adalah isu terorisme.

\section{ISLAM:TARGET POLITIK TEROR AMERIKA ATAS NAMA KAPITALISME}

Siapapun yang mengelaborasi berbagai undangundang dan hukum tentang terorisme akan memahami dengan terang bahwa semua peraturan itu tunduk kepada orientasi politik negara-negara yang membuatnya. Sekedar contoh saja, Amerika menganggap pembunuhan Indira Gandhi sebagai aksi terorisme, sementara pembunuhan Raja Faisal dan Presiden Kennedy tidak disebut terorisme. Pada tahun 1997, awalnya AS mencap pemboman gedung Kantor Penyelidikan Federal di Oklahoma sebagai aksi teroris, 
namun setelah diketahui bahwa pelakunya adalah orang Amerika sendiri, McTimothy, pemboman yang semula dianggap terorisme itu kemudian dianggap sebagai aksi kriminal biasa. Ketika pejuang HAMAS melakukan bom syahid melawan kebrutalan tentara Israel, AS menamainya sebagai aksi terorisme. Sedangkan, ulah dan pembantaian para serdadu Israel yang memporakporandakan kalangan sipil disebutnya sebagai pembelaan hak. Peruntuhan gedung WTC yang hingga detik ini belum terbukti siapa pelakunyadisebut sebagai terorisme, sementara tindakan AS yang menghancurleburkan Afghanistan beserta 7.5 juta penduduknya dinamakannya sebagai penegakkan keadilan tanpa akhir (enduring justice). Begitu juga yang kemudian dilakukanya terhadap Irak, AS menyebutnya sebagai tindakan menghilangkan keotoriteran penguasa. Itulah arti terorisme yang mereka definisikan.

Melihat realitasnya, termasuk dengan membaca laporan resmi Departemen Luar Negeri AS, seruan anti terorisme tersebut ditujukan kepada kelompok yang anti terhadap kezhaliman, penjajahan dan kesewenangwenangan AS dan negara-negara kapitalis sekutunya. Kelompok Islam Politik merupakan kelompok yang pada umumnya sangat kritis terhadap sepak terjang AS dalam percaturan internasional. Karenanya, tidak mengherankan jika dalam laporan Departemen Luar Negeri AS tentang Organisasi Teroris Dunia kita bisa melihat bahwa daftar panjang tersebut sebagian besar (50\% lebih) diisi oleh nama-nama organisasi/ kelompok Islam (http:// www.state.gov/s/ct/rls/rpt/ fto).

Mengapa sasaran sentralnya adalah Islam ?. Pertama, bisa jadi hal ini diilhami oleh tesis preskriptifnya Samuel P. Huntington tentang The Clash of Civilization, di mana dia memprediksikan bahwa berakhirnya Perang Dingin, yang menandai berakhirnya Perang Ideologi, akan dilanjutkan dengan perang baru yang disebut Perang Peradaban. Jika selama ini perang lebih banyak terjadi intern Peradaban Barat, maka perang baru ini adalah perang antara Peradaban Barat (dipelopori AS dan Eropa Barat) dengan Peradaban Timur (kekuatan Islam dan Konfusian). Dengan masukan dari Huntington ini, setidaknya kita bisa memahami bahwa eksistensi ideologi yang diemban oleh AS membutuhkan adanya musuh/lawan dari ideologi tersebut. Islam merupakan kunci dari kebijakan luar negeri AS pasca keruntuhan sosialismekomunisme. Isu terorisme sebenarnya merupakan kelanjutan saja dari isu tirani-otoriter, isu agresor, isu pelanggaran HAM dan yang sejenisnya.

Karena itu pula negeri-negeri Islam ${ }^{1}$ menjadi wilayah terpenting yang menjadi sasaran Amerika dalam penerapan gagasan antiterorisme. Salah satu wujudnya berupa tekanan untuk membela AS atas nama 'memberantas terorisme'. Sebagai contohnya, sesaat setelah peledakan gedung kembar WTC, 11 September 2001, pemerintaha AS memberikan pilihan kepada seluruh dunia apakah berada di belakang AS ataukah berada di belakang teroris. Bila tidak berpihak kepada AS berarti ada di pihak teroris yang berhak mendapatkan serangan tongkat (stick). Afganistan merupakan contoh konkrit negeri Islam yang mendapat tongkat ini. Wujud yang lain berupa tekanan kepada dunia Islam untuk membuat undangundang antiterorisme yang persis seperti yang dibuat AS.

Kedua, dengan menggunakan kerangka ideologi yang diemban oleh AS, yaitu kapitalisme, kita juga bisa melihat motif lain munculnya isu terorisme. Tujuan tertinggi dalam kapitalisme adalah the highest rate of return (mendapatkan keuntungan yang setinggitingginya) (Jones, 1992:2). Kita tahu bahwa negerinegeri Islam merupakan kawasan yang secara ekonomi dan politik sangat strategis. Sehingga terlihat dengan jelas bahwa seluruh upaya mobilisasi militer AS di Afganistan ditujukan untuk menancapkan secara paksa pengaruh politik dan ekonominya di sana (Shaheed dan Muhammad, 2001). Dalam rangka mengokohkan cengkeraman Amerika di negeri-negeri Islam serta melestarikannya agar tetap berada dibawah hegemoni AS, sasaran Amerika adalah pada terpecahnya harmonisasi hubungan penguasa dan rakyat di negerinegeri tersebut. Maka sasaran Amerika sesungguhnya adalah kaum muslim di negeri-negeri Islam tersebut yang sedang merintis menerapkan syariat Islam untuk 
menyelamatkannya dari kehancuran akibat kapitalisme. Padahal, AS dan negara-negara sekutunya mengerti betul bahwa penerapan Islam dalam institusi politik yang berupa negara (kekhilafahan) merupakan ancaman serius bagi keadikuasaan kapitalisme pimpinan Amerika. Berdasarkan hal tersebut, tidak mengherankan setiap gerakan Islam atau partai-partai Islam, yang menghendaki diterapkannya syariat Islam melalui tegaknya institusi politik Negara Islam,. dicap teroris. Paling tidak, selalu dicurigai. Sekalipun, mereka tidak melakukan kekerasan dan anti kekerasan. Alasannya, semua itu dianggap oleh AS akan menghalangi dan menjadi batu sandungan bagi kepentingan dan eksistensinya di seluruh dunia. Jadi cap yang diberikan AS dan negara-negara lain-bahwa Islam itu identik dengan terorisme-adalah cap yang tendensius, dipolitisasi, dan direkayasa oleh AS serta berbagai kekuatan politik lain dalam rangka melestarikan eksistensi mereka.

\section{AMERIKA SEBAGAI INDUK TERORISME}

Berbicara tentang aktifitas penggunaan kekerasan yang mengancam atau menghilangkan nyawa manusia perlu kiranya dikemukakan dua sebab berbeda, yang telah melahirkan terorisme. Yang pertama, terorisme muncul karena ada sebuah kekuasaan durjana dan durhaka, yang ingin menundukkan masyarakat tidak berdosa agar menjadi lemah lunglai dan tidak punya nyali kembali untuk mengangkat kepala serta melakukan perlawanan terhadap kekuatan durjana itu. Sebaliknya ada terorisme yang disebabkan oleh keputusasaan dan rasa frustrasi yang meluas di pihak si lemah, kemudian si lemah tidak bisa memberikan perlawanan kepada penindasan yang dideritanya kecuali dengan melakukan teror, agar si penindas atau si durhaka bisa mulai melepaskan cengkeramannya. Dengan kata lain, supaya si penindas yang kejam itu juga kemudian mengalami rasa takut untuk melanjutkan penindasan dan kedurjanaannya. Orang pun akhirnya memahami ada terorisme kecil-kecilan yang dilakukan segelintir orang-orang yang tertindas. Tetapi juga ada terorisme berskala raksasa yang sangat dahsyat, yang disponsori oleh negara dengan aparat militer maupun aparat kekerasannya.

Dalam kasus di Timur Tengah kita bisa menyebutkan bahwa Israel dengan kekuatan persenjataan yang dimobilisir oleh negara merupakan contoh terorisme yang pertama, sementara aksi-aksi bom bunuh diri yang dilakukan oleh warga Palestina hanyalah merupakan terorisme yang kedua. Sementara kita mengetahui betapa dalam setiap konflik ArabIsrael terjadi suplai besar-besaran persenjataan dan finansial dari negara-negara Barat (yang dimotori oleh Amerika Serikat)(Muslihati, 1993). Begitu juga kita bisa melihat bahwa dalam banyak kasus konflik dan kekerasan yang terjadi di negeri-negeri Islam lainnya ada permainan politik Barat. Upaya menciptakan ketakutan itu dilakukan oleh Amerika supaya muncul kebutuhan akan peningkatan anggaran militer pada negara-negara sasaran Amerika. Dalam hal ini Amerika berada dalam posisi melindungi anaknya yang berupa perusahaan multinasional (khususnya Komplek Industri Militer) (Jones, 1992:124).

Dari paparan ini kita bisa menyimpulkan bahwa sesungguhnya Amerika itulah induknya terorisme, karena dialah yang paling mempunyai kekuatan untuk menciptakan, melindungi dan mempertahankan terjadinya terorisme. Menurut Amien Rais perbedaan antara orang baik dan orang jahat adalah, orang yang termasuk kategori baik tidak pernah menghalalkan cara untuk mencapai tujuannya. Sementara orang yang termasuk kategori buruk dan busuk, adalah mereka yang setiap kali dengan entengnya menggunakan prinsip tujuan menghalalkan cara. Saya kira Amerika termasuk dalam kelompok yang kedua ini.

\section{PANDANGAN ISLAM TENTANG TERORISME}

Terorisme sebagai kekerasan politik, secara normatif bertentangan dengan etos kemanusiaan Islam. Karena Islam mengajarkan etos kemanusiaan, yang sangat menekankan kemanusiaan universal. Aqidah Islam 'Laa ilaha illa Allah, Muhammad Rasulullah', sebagai asas yang manusiawi, telah menjadi dasar bagi seluruh bentuk hubungan yang dijalankan kaum Muslim; menjadi pandangan hidup yang khas dan hanya dimiliki oleh kaum Muslim; menjadi dasar dalam 
menyingkirkan kedzaliman dan menyelesaikan perselisihan; menjadi dasar dalam kegiatan ekonomi dan perdagangan; menjadi dasar bagi aktivitas dan kurikulum pendidikan; menjadi dasar dalam membangun kekuatan militer; menjadi dasar dalam politik dalam dan luar negeri; termasuk menjadi dasar bagi negara dan kekuasaan. Tidak cukup sampai di situ, Islam juga menganjurkan dan memberikan justifikasi kepada Muslim untuk berjuang, berperang dan menggunakan kekerasan terhadap para penindas, musuh-musuh Islam dan pihak luar yang menunjukkan sikap bermusuhan dan tidak mau hidup damai dengan Islam dan kaum Muslimin (lihat QS 2:190-191, 8:59-60, 9:36,38, 33:60-62, 49:9-10).

Dalam masalah jihad fi sabilillah, sesungguhnya target dan tujuannya sangat jelas, yaitu untuk menyebarluaskan aqidah ini kepada seluruh ummat manusia. ${ }^{2}$ Sabda Rasulullah saw:

"Aku telah diperintahkan untuk memerangi manusia hingga mereka mengatakan -mengakui- Laa ilaha illa Allah Muhammad Rasulullah. Apabila mereka mengakuinya maka darah dan harta mereka terpelihara dariku, kecuali dengan haq -jika melanggar syara-."

Ini menunjukkan bahwa negara Khilafah Islamiyah adalah negara yang dibangun dan berdiri di atas landasan mabda (ideologi). Dijadikannya aqidah Islam sebagai asas negara dan kekuasaan, bukan sekedar formalitas atau perlambang saja, melainkan tampak dalam seluruh bentuk interaksi masyarakat dan negaranya. Oleh karena itu Negara Khilafah Islamiyah tidak akan mentolerir seluruh bentuk pemikiran maupun hukum/perundang-undangan, kecuali terpancar dari aqidah Islam.

Aqidah Islam yang menjadi dasar bagi mabda (ideologi) ini pula yang mengharuskan negara Khilafah Islamiyah untuk menyebarluaskan risalah Islam ke seluruh penjuru dunia. Penyebarluasan dakwah Islam oleh negara Khilafah dianggap sebagai asas negara Khilafah dalam membangun hubungannya dengan negara-negara lain. Dengan kata lain menjadi dasar politik luar negeri negara Khilafah Islamiyah terhadap hubungannya dengan negara-negara lain. Bukankah
Rasulullah saw sejak diutus menjadi Rasulullah, lalu berhasil membangun Daulah Islamiyah di kota Madinah, hingga wafatnya, senantiasa menyampaikan dan menyebarluaskan risalah Islam ini kepada ummat manusia? Dan bukankah kewajiban tersebut dilanjutkan oleh para Khulafa Daulah Islamiyah selama berabad-abad, hingga risalah Islam dan futuhat Islam mencapai negeri-negeri yang sangat jauh dan luas? Karakter penyebarluasan risalah Islam ke seluruh dunia, tampak dalam firman Allah Swt:

"Dan Kami tidak mengutus kamu (Muhammad) melainkan kepada ummat manusia seluruhnya, sebagai pembawa berita gembira dan pemberi peringatan." (QS. Saba' [34]:28)

Mula-mula Rasulullah saw menyampaikan dan menyebarluaskan risalah Islam kepada karib keluarganya, kemudian melebar kepada penduduk kota Makkah; dan setelah Daulah Islamiyah berhasil dibangun di kota Madinah, dakwah Islam melebar ke seluruh Jazirah Arab. Pada masa Khulafa ar-Rasyidin makin meluas hingga berhasil membuka dan menaklukkan wilayah-wilayah Persia, Syam, Mesir, Afrika Utara, dan kawasan Asia Tengah. Kurun berikutnya dakwah Islam sampai ke jantung Eropa, menaklukkan setengah wilayah Perancis, menyentuh gerbang kota Wina (Austria), bahkan ke kawasan Timur telah sampai juga di wilayah Asia Pasifik (Indonesia). Hal ini menunjukkan bahwa Rasulullah saw dan kaum Muslim terdahulu telah meletakkan penyebarluasan mabda (ideologi) ke seluruh dunia, dengan jalan/metode (thariqah) jihad fi sabilillah.

Meskipun demikian, sepanjang sejarah negara Khilafah, kaum Muslim tidak pernah memulai peperangan menghadapi musuh-musuhnya, kecuali telah disampaikan kepada mereka tiga pilihan; yaitu, memeluk Islam, membayar jizyah (dan wilayahnya tunduk ke dalam naungan negara Khilafah), -jika dua pilihan terdahulu ditolak- maka berarti perang.

Pilihan pertama yang disampaikan negara Khilafah kepada negara-negara kafir adalah seruan untuk memeluk Islam. Jika mereka menerima dan memeluk Islam, maka mereka memperoleh keselamatan di dunia 
dan di Akhirat. Hak-hak dan kewajiban mereka sama dengan hak-hak dan kewajiban yang dimiliki oleh kaum Muslim lainnya, sebagai warga negara khilafah Islamiyah. Darah (jiwa), harta dan kehormatan mereka terjaga. Negeri mereka akan berada di bawah panjipanji 'Laa ilaha illa Allah', bergabung dengan negara Khilafah.

Apabila mereka menolak pilihan pertama, maka disampaikan kepada mereka pilihan kedua, yaitu membayar jizyah. Jizyah berfungsi sebagai pengunci peperangan, penjaga jiwa (darah) mereka. Namun, negeri mereka berada di bawah kekuasaan negara Khilafah, yang di dalamnya diterapkan sistem hukum Islam. Bagi orang-orang kafir yang menolak memeluk Islam, kepada mereka diberi kebebasan memilih. Hanya saja wajib atas mereka membayar jizyah, sebagai jaminan perlindungan atas darah, kehormatan dan harta mereka di bawah kekuasaan negara Khilafah, serta kebebasan mereka untuk menjalankan ibadah menurut agamanya.

Akan tetapi, jika mereka menolak dua pilihan sebelumnya, maka berarti mereka memilih untuk berperang dengan negara Khilafah. Sabda Rasulullah saw melalui Buraidah ra, yang berkata:

"Rasulullah saw, apabila memerintahkan komandan perangnya (berperang), beliau menasehatinya -terutamasupaya bertakwa kepada Allah, dan-semoga-kaum Muslim yang turut bersamanya dalam keadaan baik, kemudian bersabda:'... Jika engkau berjumpa dengan kaum Musyrik, berikanlah kepada mereka tiga pilihan atau kesempatan -bila mereka menyambut, terimalahdan cukuplah atas apa yang mereka lakukan; (yaitu) serulah mereka kepada Islam, jika mereka menyambutnya maka terimalah dan cukuplah dari yang mereka utarakan. Kemudian serulah mereka supaya berpindah ke negeri Muhajirin. Apabila mereka menolak pindah, beritahukan bahwa mereka-kedudukannya-seperti orangorang Arab Muslim yang berlaku juga hukum Allah sebagaimana terhadap orang-orang Mukmin. Mereka tidak memperoleh ghanimah dan fa'I kecuali turut serta berjihad dengan kaum Muslim. Namun, jika mereka menolak (pilihan pertama ini) maka pungutlah jizyah.

Dan bila mereka menyambutnya, terimalah dan cukuplah dari yang mereka utarakan. Akan tetapi jika mereka menolak juga (pilihan kedua), maka mintalah pertolongan kepada Allah dan perangilah mereka." (HR. Muslim)

Hadits Rasulullah saw ini menggambarkan bahwa peperangan merupakan alternatif terakhir. Seruan pertama justru seruan untuk memeluk Islam. Jika mereka menerimanya, maka mereka tidak boleh diperangi. Jiwa, harta dan kehormatan mereka sama seperti kaum Muslim, wajib dipelihara dan dijaga.

Jihad fi sabilillah di dalam Islam bukan untuk menaklukkan ummat manusia, menguras dan mengeksploitasi harta kekayaan negeri lain, apalagi memusnahkan sekelompok ummat manusia dari muka bumi. Seruan dan pelaksanaan jihad fi sabilillah dalam Islam adalah dalam rangka mengagungkan kalimat Allah, menyebarluaskan risalah Islam dan menyingkirkan kesesatan, kekufuran, kedzaliman di tengah-tengah ummat manusia (Arsyad,2002:40-46). Menghancurkan berbagai penghalang fisik dan ideologi yang selama ini telah membatasi ummat manusia sehingga kebenaran, cahaya dan petunjuk Allah Swt tidak sampai dengan benar kepada mereka. Dengan demikian, jihad fi sabilillah tidak sama dengan format peperangan (dan penjajahan) yang dilakukan oleh peradaban Barat terhadap negeri-negeri lain.

Disamping itu, ayat-ayat Al-Quran maupun haditshadits Nabi saw menjelaskan kepada kita bahwa sebelum peperangan terjadi argumentasi dan perdebatan dengan negeri-negeri kufur. Firman Allah Swt:

"Serulah (manusia) kepada jalan Rabb-mu dengan hikmah (argumentasi) dan pelajaran yang baik (nasehat yang halus), dan bantahlah mereka (berdebat) dengan cara yang baik." (QS. An-Nahl [16]:125)

Bukankah Rasulullah saw sebelum melakukan futuhat ke berbagai wilayah, didahului dengan pengiriman utusan kepada para penguasa kufur? Mengajak mereka memeluk Islam, dan berdialog dengan mereka untuk membuktikan kebathilan ajaranajaran kufur dan menunjukkan kelayakan ajaran Islam? 
Bahkan Rasulullah saw telah memilih untuk mengambil jalan damai, meskipun disitu terdapat peluang besar untuk melanjutkan peperangan. Pada saat kaum Muslim berhasil membuka kota Makkah, dan orang-orang kafir berputus asa, Rasulullah saw tidak melampiaskannya dengan membinasakan dan memerangi mereka. Yang dilakukan Rasulullah saw adalah menyeru mereka seraya bersabda:

"Pergilah kalian (kemana saja kalian suka), karena kalian telah bebas."

Berdasarkan penuturan singkat diatas, maka sesungguhnya perdamaian merupakan hukum asal dari hubungan internasional antara kaum Muslim (negara Khilafah Islamiyah) dengan negeri-negeri (ummatummat) lain. Predikat Islam sebagai teroris itu tidak sesuai dengan fakta yang ada dan tidak sesuai dengan yang dikehendaki oleh Allah. Allah Swt. berfirman:

Tidaklah Kami mengutus engkau (Muhammad) melainkan untuk menjadi rahmat bagi semesta alam. (QS al-Anbiya' [21]:107).

\section{KESIMPULAN}

Dari paparan di atas, bisa kita tarik benang merah bahwa terorisme sebagai tindakan menimbulkan ketakutan massa, bagaimana pun bertentangan dengan nilai-nilai kemanusiaan. Usaha-usaha memerangi terorisme dalam bentuk apa pun, seharusnya tidak dilakukan dengan cara-cara kekerasan, seperti yang terjadi dalam krisis AS-Afganistan. Kalau saja ada orang-orang Islam yang menggunakan cara-cara kekerasan sehingga menimbulkan ketakutan pada pihak yang tidak seharusnya, kita pun harus melakukan koreksi. Tetapi untuk memahami bagaimana terorisme menjadi isu global, tentunya kita perlu memahami bagaimana konstelasi politik dunia saat ini.

Usaha memerangi terorisme harus berangkat dari penyelesaian terhadap akar masalah (core of problems). Salah satu akar terpenting terorisme saat ini adalah ketidakadilan dan kepincangan dalam tata hubungan internasional (Arsyad,2002:40-46), yang pada gilirannya menumbuhkan sikap standar ganda (double standard) pada pihak pemegang dominasi dan hegemoni internasional, yakni AS dan sekutu-sekutu Baratnya. Hanya dengan terciptanya tata internasional baru yang adil, maka terorisme bisa dikurangi, dengan demikian tercipta perdamaian dunia.

\section{CATATAN AKHIR}

1 Negeri Islam adalah negara yang mayoritas penduduknya beragama Islam, meskipun hukum yang diterapkan di negara itu bukan Hukum Islam. Lihat dalam Taqyuddin An Nabhani, Nidzam al-Islam (Beirut:Daarul Umah, 1953).

2 Lihat kerangka Islam Ideologi yang ditawarkan oleh Hafidz Abdurrahman dalam Islam Politik dan Spiritual Lihat juga Taqyuddin An Nabhani, Nidzom Al-Islam, hal. 22-57.

\section{REFERENSI}

An Nabhani, Taqyuddin. 1953.Nidzam al-Islam. Beirut:Daarul Umah Arsyad,Azhar.2002. Islam dan Perdamaian Global. Yogyakarta:Madyan Press.

Azra, Azyumardi. 2002.Konflik Baru Antar Peradaban: Globalisasi, Radikalisme \& Pluralitas.Jakarta:PT Raja Grafindo Persada.

http://www. state.gov/s/ct/rls/rpt/fto

Jones, Walter S. 1992. The Logic of International Relations. Jakarta:PT Gramedia.

Muslikhati, Siti.1993." Strategi Perlindungan Amerika Serikat Terhadap Israel". Skripsi tidak dipublikasikan, Jurusan Hubungan Internasional UGM.

Papp, Daniel S.1988. Contemporary International Relations. New York:Macmillan Publishing.

Sampson,Anthony.1987. Bazar Senjata, Jakarta:Tim Pantja Simpati. Shaheed, Ahmeed dan Farhan Muhammad.2001. "Motif Lain di Balik Agresi AS" dalam Jurnal Al Wa'ie No. 15, Nov. 2001. 